\title{
Tourism planning and development: The case of Portugal's Norte region
}

\section{Planeamento e desenvolvimento do turismo: o caso da região Norte de Portugal}

\author{
Ana Paula Lopes \\ Politécnico do Porto/ISCAP - CEOS.PP, CEPESE, \\ aplopes@iscap.ipp.pt
}

Filomena Soares

Politécnico do Porto/ESHT

Rua Dr. Roberto Frias, 4200-465 Porto, Portugal, filomenasoares@eseig.ipp.pt

\begin{abstract}
Tourism has been gaining increasing importance in the global economy, in general, and, more specifically, in Europe, Portugal, and smaller areas such as Portugal's Norte region. The north of Portugal has a rich cultural, historical and architectural landscape heritage, including some pearls that the United Nations Educational, Scientific and Cultural Organisation has classified over the years as World Heritage Sites. With its wideranging impact on economic growth, employment and social development, tourism can be a powerful tool with which to shape the Portuguese economy, contributing to the country's competitiveness, richness and cohesion. Therefore, the government and tourism stakeholders have recently made a stronger commitment to developing this sector. The goal of this study was to analyse tourism policies' contributions to the development of the tourism sector in the northernmost region of Portugal, included in the National Strategic Plan for Tourism (PENT) and in the Regional North Tourism Agenda (ART). This study sought to achieve these objectives by focusing on two main aspects. First, it examined the characteristics of the sector, identifying the tourism products in the Norte region. Second, this research analysed the overall picture of the sector's development between 2004 and 2014. For that, we made a descriptive analysis of the main tourism indicators based on data collected from several sources, namely the Instituto Nacional de Estatistica (National Statistics Institute) (INE), PENT, the Comissão de Coordenação e Desenvolvimento Regional do Norte (Northern Portugal Regional Coordination and Development Commission), Turismo de Portugal (Tourism of Portugal) and Turismo do Porto e Norte de Portugal (Tourism of Oporto and Northern Portugal). The results reveal that investment in tourism in the Norte region has included offering eight primary tourism products and differentiators in four tourism subregions (i.e. Oporto Metropolitan Area, Alto Minho, Douro and Terras de Trás-os-Montes). Comparing the forecast values in terms of overnight stays, tourists and revenue set by PENT, the reality showed that the results were a little bit far from the expected; however, the findings confirm the common perception that Portugal's Norte region is still experiencing a trend towards growth as a tourist destination.
\end{abstract}

Keywords: Norte region, sustainable tourism, tourism planning, regional competitiveness.

\section{Resumo}

O turismo tem vindo a ganhar cada vez mais importância na economia global, em geral e mais especificamente, na Europa, em Portugal e em áreas mais pequenas, como a região Norte de Portugal. O norte de Portugal possui um património paisagístico, cultural, histórico e arquitetónico muito rico, incluindo algumas "pérolas" que a Organização das Nações Unidas para a Educação, a Ciência e a Cultura classificaram ao longo dos anos como Património Mundial. Com o seu vasto impacto no crescimento económico, emprego e desenvolvimento social, o turismo pode ser uma ferramenta poderosa na transformação da economia portuguesa, contribuindo para a competitividade, a riqueza e a coesão do país. Neste sentido, o governo e os intervenientes no domínio do turismo assumiram recentemente um compromisso mais forte no desenvolvimento desse setor. O objetivo deste estudo foi analisar de que modo as políticas públicas de turismo contribuem para o desenvolvimento do setor de turismo na região norte de Portugal, incluídas no Plano Estratégico Nacional de Turismo (PENT) e na Agenda Regional de Turismo Norte (ART). Procurou-se atingir esses objetivos focalizando dois aspectos principais. Primeiro, examinaram-se as características do setor, identificando os produtos turísticos na região Norte. Em segundo lugar, analisamos o panorama geral do desenvolvimento do setor entre 2004 e 2014, fazendo uma análise descritiva dos principais indicadores turísticos com base em dados recolhidos de várias fontes, nomeadamente o Instituto Nacional de Estatística (INE), PENT, a Comissão de Coordenação e Desenvolvimento Regional do Norte, Turismo de Portugal e Turismo do Porto e Norte de Portugal. Os resultados revelam que o investimento no turismo na região Norte incluiu a oferta de oito principais produtos turísticos e diferenciadores em quatro sub-regiões de turismo (ou seja, área metropolitana do Porto, Alto Minho, Douro e Terras de Trás-os-Montes). Comparando os valores de previsão em termos de dormidas, turistas e receitas fixadas pelo PENT, a realidade mostrou que os resultados estavam um pouco distantes do esperado; no entanto, confirmam a percepção comum de que a região Norte de Portugal ainda está em pleno crescimento como destino turístico.

Palavras-Chave: Região Norte, turismo sustentável, planeamento turístico, competitividade regional.

\section{Introduction}

In recent years, tourism has experienced continuous growth and deepening diversification, becoming one of the fastest growing economic sectors around the world. According to the United Nations World Tourism Organisation's (UNWTO) 2014 Annual Report (UNWTO, 2015), international tourism expanded significantly in 2014, as the number of international tourists (i.e. overnight visitors) grew $4.4 \%$ for an additional 48 million more tourists than in 2013, reaching a new record total of 1,135 million. This caps five consecutive years of above average growth since the global economic crisis of 2009. With this $4.4 \%$ increase, international tourism once again exceeded UNWTO's long-term forecast of $3.8 \%$ annual growth for the period 2010-2020, reflecting the sector's strong and consistent performance in the face of global challenges. In their last annual research report, the World Travel and Tourism Council (WTTC, 2016) estimates that 
the travel and tourism sector now accounts for $9.8 \%$ of global gross domestic product (GDP) - a total of US\$ 7.2 trillion and 284 million people employed or 1 in 11 jobs on the planet. This industry's growth rate of $3.1 \%$ is faster than that of the overall global economy. Despite major challenges, it is predicted that this sector will continue to outperform global GDP growth in 2016. According to Crotti and Misrahi (2015), the tourism sector is forecast to continue growing at $4 \%$ annually, which is faster than financial services, transport and manufacturing.

Portugal emerged as an international tourist destination in the twentieth century, in the 60s, when Europeans discovered the hills and beaches of the Algarve region. Since that time, foreign tourists' expenditures, such as for housing and other services, have allowed Portugal to maintain a smaller deficit in its balance of payments, a higher economic growth and sustainable development in some regions popular with tourists (Turismo de Portugal, 2007). Notably, Portugal currently is ranked fifteenth among 141 countries by the Travel and Tourism Competitiveness Index 2015, which seeks to measure the factors and policies that encourage a strong tourism sector and attract travellers in different countries or tourist destinations globally (Crotti \& Misrahi, 2015). Tourism is one of the Portuguese economy's key sectors, and its relative weight has grown over recent years. It plays an important role in the economic fabric of Portugal, both in production and employment. This sector generates a larger number of tourism activities in certain geographical areas, makes a greater contribution to specific regions' growth and decreases the economic imbalance between regions in several parts of the country. This is particularly important for Portugal given its existing tourism offer, but, above all, this sector strength highlights the country's tourism potential based on beaches, museums, history, nature, wines, regional products, culture and so on (Leitão, 2011).

Aware of this importance, the Portuguese government has given the tourism sector priority on its agenda, both nationally and regionally, which resulted in the approval of the Plano Estratégico Nacional do Turismo (National Strategic Plan for Tourism) (PENT), implemented in 2007. The plan's objectives were to secure Portugal's ranking as a leading tourism destination and to develop a 'new' industry that might contribute to the economic growth of the country. The prospect of strong growth in the world tourism market creates an opportunity for Portugal, but strategic action is essential to enable the country to respond to both increasingly sophisticated demands and the growing number of competing destinations. Portugal needs to become one of the fastest-growing destinations in Europe, through development grounded in upgrading and offering more competitive products, thereby converting tourism into one of the principal drivers of growth in the national economy. The value proposition for the country centres on the key factors that distinguish Portugal from other competing destinations - 'climate and light'; 'history, culture and tradition'; 'hospitality' and 'concentrated diversity' - and on elements that add value to Portugal in the context of tourists' decisions - 'contemporary authenticity', 'safety' and 'competitive quality' (Turismo de Portugal, 2007, p. 5).
According to Kim and Kim (2013), tourism is one of the mainstays of regional development, understood here not only as the economic growth of regions but also their social and environmental sustainability. Makhlouf (2012) reports that investment in the tourism sector generates two significant effects: i) an increase in tourist spending and increased employment in local and national sectors and ii) the construction of tourism infrastructure such as roads, airports, museums, amusement parks, health facilities and hotels. These effects have a positive impact on resident populations' quality of life, resulting in patterns that 'relate tourism to economic and regional development'.

In the past few years, an accentuated growth of research on tourism has been observed in Portugal. This is a definite sign of a growing interest in high education institutions in understanding and drawing lessons from the realities of Portuguese tourism, as well as a greater acceptance of the importance of tourism as a research field (Silva, Rodrigues, Mendes \& Pereira, 2010).

Given the importance that tourism has in the Norte (North) region of Portugal, this study sought to analyse some tourism policies' contributions to the development of this specific region. The present study will be presented as follows. Section two covers a literature review that includes a set of resources and tourism products in northern Portugal in special for the region's tourism sub regions (i.e. Área Metropolitana do Porto, Alto Minho, Douro and Terras de Trás-os-Montes). Section three presents the methodology used and data analysed in this study. Section four discusses our analyses' results, and section five draws conclusions based on the research.

\section{Literature review}

Tourism plays an important role in any country's economy. According to Benur and Bramwell (2015), the diversification, intensification and linkage of tourism products can be crucial for destinations' successful development. Most countries, in general, allow the tourism industry to be driven and developed locally (Choi \& Sirakaya, 2005). Nevertheless, the development of tourism infrastructure, in particular, has a tendency to be geographically concentrated, driven by complex social processes and targeted at tourist markets that do not fit into the types of objectives set out by national governments in their tourism policy frameworks (Visser, 2003). Before developing any economic development strategies for a region or country, policymakers need to identify the main economic, natural, cultural and heritage resources. In the case of tourism, it is necessary to identify potential generators of tourism resources with distinctive and possibly unique characteristics, in order to develop one or more tourism products.

Tourism products are a mix of all the 'bits and pieces' that individuals can consume, use, experiment, observe and enjoy during a journey or stay (Masiero \& Nicolau, 2012). These products are considered packages of tangible and intangible components based on specific activities in given destinations (Middleton, Fyall, Morgan \& Ranchhod, 2009). However, the cited authors add that these packages are seen by tourists as experiences available at a given price. The cited authors suggest 
that tourism products can be divided into two levels: the overall level that includes all the experiences that tourists face from their departure to their return and the specific level that relates to a component offered by a particular organisation. According to $\mathrm{Xu}$ (2010), tourists see tourism products as complete experiences that meet their multiple needs and provide corresponding benefits. A typology of strategic options for tourism product development and assembly in destinations is based on the degree of intensification, concentration and diversification of tourism products (Benur \& Bramwell, 2015). Smith (1994) defines tourism products as consisting of five elements: the physical space, services, hospitality, freedom of choice and involvement. Thus, tourism products are the available goods or services with tangible and intangible characteristics that tourists can consume, use, observe, enjoy and experiment with during a trip or stay - at a certain price.

According to Weiermair (2004), the production and marketing of tourism products is distinct from industrial products, and tourism products display particular characteristics that often pose constraints or problems and, hence, provide opportunities for increasing the value of products via innovation. Tourism produces and sells product bundles, instead of single products, that are extremely intangible experiences and products that cannot be stored.

Fernandes and Cepeda (2002) and Lage and Milone (2001) argue that tourism products can be analysed from three different perspectives. The first is primary (i.e. basic) resources resulting from both nature and human actions and constituting a prerequisite for the emergence of tourism products. The second involves secondary resources (i.e. facilities) meeting the needs of tourists, whose creation is conditioned by tourist flows and demands (e.g. accommodation units). The last is tertiary (i.e. complementary) resources serving the general population (i.e. resident and floating) but, in particular, residents. From this perspective, the latter resources are classified as a complementary element of tourism products.
For the cited authors, the components that comprise tourism products are, first, tourism resources - all the elements that create tourist attractions - which can be natural, cultural, artistic, historical or technological. These include the destinations' positive attributes that attract visitors and strengthen tourism products. The second component is infrastructure - a set of buildings and equipment that comes with the development of human activities, of both residents and visitors. The third is super-structures - the skills necessary to accommodate and fill tourists' free time and keep them in the tourist destination. The fourth is welcome and culture, which involve the human spirit, attitudes and behaviours that exist at the tourist destination and that are selected by visitors, including cultural events. The last component is accessibility, which is composed of external transport facilities and their related services and prices.

In order to gain a better understanding of what tourism products are, they must be analysed in terms of attractions, facilities and accessibility (Patel \& Nayab, 2014). Attractions are defined as the tourism product elements that motivate tourists to choose to visit a specific place as opposed to another, that is, factors that generate the flow of visitors to a particular location. Facilities are those elements in tourism products that are necessary aids to tourism attractions. The absence of facilities means that tourists may stop visiting the sights. Accessibility includes transport and roads so that tourism can be enjoyed with through more social interactions and greater local integration.

In the present study, we used the new common NUTS (2013). The NUTS system subdivides nations into three levels: NUTS Inations, NUTS II - regions and NUTS III - sub regions. The Portuguese NUTS 2013 were set out in the European Commission (EC) No. 868/2014 regulations, and they have been in use within the European and national statistical systems since 1 January, 2015. The territorial division of Portugal into NUTS II regions is presented in Figure 1.

\section{Figure 1 - Territorial division of Portugal by NUTS II regions}

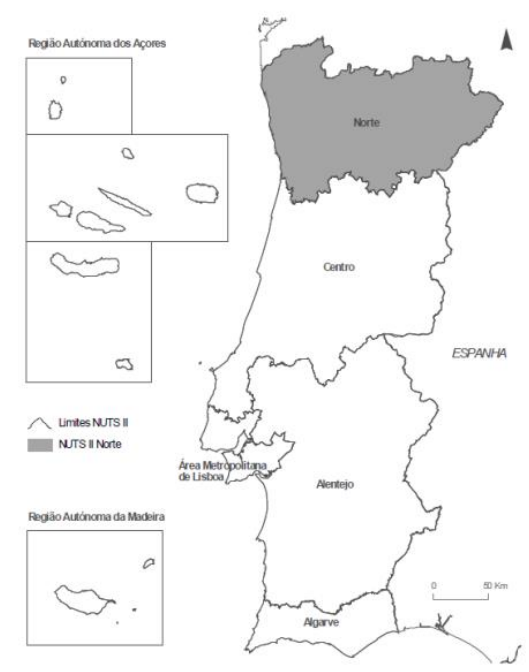

Source: INE (2015a). 
According to this new version, the NUTS III reconfiguration process was carried out in coordination with the reorganisation of local administrations and, in particular, with the creation of the Portuguese mainland's inter-municipal entities, which include inter-municipal communities and metropolitan areas, as defined by Law No. 75/2013. The Portuguese NUTS III divisions were reduced from 30 to 25 territorial units. The territorial administrative divisions at the municipality level - the territorial units of reference for the majority of the information made available for this study - are those created by the administrative reorganisation, in use since 30 September, 2013. The NUTS II territorial division of the Norte region, NUTS III and municipalities are presented in Figure 2.

Figure 2 - NUTS II territorial division of the Norte region, NUTS III and municipalities

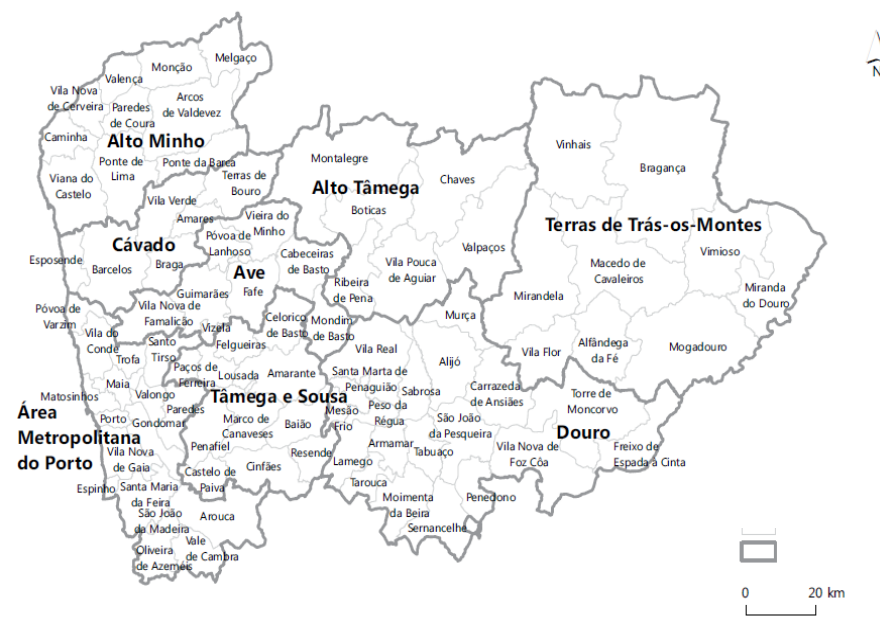

Source: INE (2015a).

With about 3.6 million inhabitants and $54 \%$ of the national working population, the Norte region includes almost $35 \%$ of the resident population in Portugal, provides close to $39 \%$ of national exports and accounts for about $29 \%$ of Portugal's GDP (INE, 2015a). Its 144 kilometres of Atlantic coastline offer further opportunities for internationalisation and business communication, constituting an ancient connection to the sea that is the basis of a unique cultural and historical heritage. Characterised as entrepreneurial, industrial and young and considered one of the safest regions, northern Portugal has also taken advantage of various United Nations Educational, Scientific and Cultural Organisation (UNESCO) World Heritage Site classifications to restore urban, historical and natural areas with strong potential for internationalisation and tourism.

The development of science, technology and innovation policies is mainly the central government's responsibility, but these policies are partly implemented at the regional level by the CCDRs, which have financial and administrative autonomy and which are entitled to implement their own regional operational programmes (ROPs) in line with key national policies. The CCDRs manage ROPs, which include initiatives aimed at promoting local innovation.

The Norte 2015 (CCDR-N, 2006) report sought to outline a vision and strategic plan for the Norte Region between 2006 and 2015. The Tourism 2020 plan launched by the Portuguese government for the 2014-2020 period is the new action plan for the development of tourism in Portugal, which defines objectives and investment priorities until 2020 for national tourism in relation to projects supported by European Union (EU) funds. It is expected that this plan's implementation will enable the sector to receive more than EUR€ 780 million in EU support over the next five years. Both plans identify a wide and diverse range of tourist resources of the Norte region, which are grouped into four major tourism areas, each with its own specific target tourist segment. These features and areas are shown in Table 1.

Table 1 - Tourism resources by tourist regions of northern Portugal

Historic centre of Oporto
Historical and cultural heritage
Entertainment and events
Gaia wine cellars - Port wine and Rabelo boats
Culture and knowledge
Economic and business centre
Douro Valley conferences, conventions and seminars
Foz do Douro and shorelines




\begin{tabular}{|c|c|}
\hline Alto Minho & $\begin{array}{l}\text { Historical and religious heritage } \\
\text { Diversity of historical cities and villages (Ponte de Lima and Viana do Castelo) } \\
\text { Lima Valley and natural parks (e.g. Peneda-Gerês National Park) } \\
\text { Shorelines } \\
\text { Fairs and festivals } \\
\text { Food and vinho verde (green wine) } \\
\text { Rural villages and solars (manors) }\end{array}$ \\
\hline Douro & $\begin{array}{l}\text { Alto Douro Wine Region - World Heritage } \\
\text { Douro River - fairways } \\
\text { Grape harvest and associated traditions } \\
\text { Nine producing villages and quintas (farms) } \\
\text { Gatural parks and reservoirs (e.g. Alvão Park and Douro International Park) } \\
\text { Foz Côa Archaeological Park - World Heritage Site }\end{array}$ \\
\hline $\begin{array}{l}\text { Terras de } \\
\text { Trás-os- Montes }\end{array}$ & $\begin{array}{l}\text { Mountain plateaus - nature and landscape (e.g. Montesinho Park) } \\
\text { Historical and cultural heritage } \\
\text { Thermal spas } \\
\text { Hunting and fishing } \\
\text { Rural villages } \\
\text { Gastronomy } \\
\text { Local products and handicraft }\end{array}$ \\
\hline
\end{tabular}

Source: Authors; adapted from CCDR-N $(2006,2014)$.

Portugal has the necessary raw materials - climate and natural and cultural resources - to enable the development and consolidation of strategic tourism products. These are sun and beach, cultural and landscape tours, city break, meetings and conferences, nature tourism, nautical tourism (including cruises), health and wellness, golf tourism, residential tourism and integrated resorts and gastronomy and wines.

According to the Ministry of Economy and Employment (Ministério da Economia e do Emprego, 2012), all primary tourism products have been selected on the basis of Portugal's resources and distinctive features, as well as their long-term growth potential. The products with the potential to catalyse short-term growth in the Norte Region are city breaks, tours and nature tourism. In addition, the region has the potential to offer more structured products, including meetings and conferences, health and wellness and gastronomy and wines, among others. In Table 2, we present a summary of initiatives to develop the Norte Region, by product, along with some related transversal initiatives.

\section{Table 2 - Primary tourism products of the Norte Region}

\begin{tabular}{|c|c|c|c|}
\hline Tourism products & Distinctive features & Main initiatives to be developed & Transversal initiatives \\
\hline $\begin{array}{l}\text { Business tourism } \\
\text { (meetings and } \\
\text { conferences) }\end{array}$ & $\begin{array}{l}\text { Culture and knowledge } \\
\text { Economy and business centre } \\
\text { Douro Valley conferences, conventions and } \\
\text { seminars } \\
\text { Leading hotel offer located in Boavista (Oporto) } \\
\text { Cultural and wine and gastronomy attractions in } \\
\text { the city (Oporto) }\end{array}$ & $\begin{array}{l}\text { Develop infrastructure for large-scale } \\
\text { conferences }(+1,000 \text { people }) \text { in the city of } \\
\text { Oporto } \\
\text { Coordination of attractions of these events } \\
\text { with other } \\
\text { regions }\end{array}$ & \multirow{5}{*}{$\begin{array}{l}\text { - Increase the quality } \\
\text { hotel offer } \\
\text { - Strengthen the charm } \\
\text { hotel offer in the Douro } \\
\text { Valley (rural hotels and } \\
\text { estates) } \\
\text { - Improve air access } \\
\text { - Improve road access } \\
\text { (secondary roads) }\end{array}$} \\
\hline City break & $\begin{array}{l}\text { Contemporary architectural spaces } \\
\text { Entertainment and events } \\
\text { Monuments and museums } \\
\text { Historical city } \\
\text { Malls }\end{array}$ & $\begin{array}{l}\text { Develop zones of tourism interest in Oporto } \\
\text { (Ribeira, historic centre and Foz) } \\
\text { Enrich the content offer in museums and } \\
\text { monuments } \\
\text { Marketing Port wine cellars }\end{array}$ & \\
\hline Nature tourism & $\begin{array}{l}\text { International Douro Natural Park } \\
\text { Esposende Coast Natural Park } \\
\text { Montesinho, Peneda-Gerês and Alvão - Natural } \\
\text { Parks } \\
\text { Lima Valley } \\
\text { Rural villages } \\
\text { Côa Valley archaeological heritage } \\
\text { Douro River - fairways and cruises }\end{array}$ & $\begin{array}{l}\text { Develop thematic routes } \\
\text { (e.g. Port wine) }\end{array}$ & \\
\hline Health and wellness & $\begin{array}{l}\text { Region with the largest number of health spas in } \\
\text { Portugal } \\
\text { Quality and diversity of thermal spa waters } \\
\text { Thermal spa emergency treatment and } \\
\text { thalassotherapy }\end{array}$ & $\begin{array}{l}\text { Develop distinctive concepts of spas for the } \\
\text { Douro region, using specific regional } \\
\text { resources } \\
\text { Enhance and stimulate expansion of } \\
\text { thermal spas }\end{array}$ & \\
\hline $\begin{array}{l}\text { Gastronomy and } \\
\text { wines }\end{array}$ & $\begin{array}{l}\text { Douro - the oldest demarcated region in the } \\
\text { world }\end{array}$ & $\begin{array}{l}\text { Foster the development of gastronomy and } \\
\text { wines clusters }\end{array}$ & \\
\hline
\end{tabular}




\begin{tabular}{|l|l|l|}
\hline & $\begin{array}{l}\text { Harvests and associated traditions } \\
\text { Port wine - international fame } \\
\text { Port wine cellars and Rabelo boats } \\
\text { Vinho verde (green wine) } \\
\text { Wine producing villages } \\
\text { Douro farms and vineyards }\end{array}$ & Develop Douro Valley activities \\
\hline $\begin{array}{l}\text { Cultural and historic } \\
\text { tourism (tours) }\end{array}$ & $\begin{array}{l}\text { Historical cities and villas' diversity } \\
\text { Traditional food } \\
\text { Local products } \\
\text { Feasts and popular festivals } \\
\text { Handicraft diversity }\end{array}$ & Develop thematic routes (e.g. Port wine) \\
\end{tabular}

Source: Authors; adapted from CCDR-N (2008a).

In 2004, tours were the primary motivation behind Portugal's tourism demand, including 44 million trips by Europeans alone, and this number was expected to rise to 79 million in 2015, the equivalent of an annual growth from $5 \%$ to $7 \%$. The main outbound markets are Italy (18\%), France $(17 \%)$, Germany $(15 \%)$ and the United Kingdom (12\%) (INE, 2015b). Tours represent the second most important motivation of tourists visiting Portugal. The large number of natural parks, monuments and cities with significant historical features, as well as the size of the country, mobility conditions and diversity of resources and attractions available within short distances, give clear comparative advantages to Portuguese destinations in terms of tours. Therefore, more tours should be developed and encouraged in the Norte region.

In the past, the European city break market's number of trips remained relatively stable, rising from 33 million trips in 1997 to 34 million trips in 2004. Experts predicted that this figure would grow to 120.6 million trips by 2015 , the equivalent of a $13.5 \%$ growth per year between 2004 and 2015 (Turismo de Portugal, 2007 , p. 65). Initiatives need to focus on the preservation and maintenance of heritage, cultural activities, public transport, safety, street cleaning and public spaces. Notably, city break tourism has a low degree of seasonality, which has a positive impact on the sustainability of employment in tourism activities, which is typically a seasonal sector.

The meetings and conferences product is especially important because of the volume of trips made and the way it contributes towards reducing destinations' seasonality. This product can be divided into two segments: association meetings - normally involving a large number of participants - and corporate meetings - involving companies and variable numbers, with a strong growth tendency. In order to attract association meetings, it is necessary to promote destinations to both event organisers and participants, given that the latter will ultimately decide whether or not to take part. Regarding corporate meetings, the companies are the ones who decide who will take part, and, therefore, the main focus should be on attracting potential meetings to the desired locations. Oporto is a priority region for initiatives in developing the meetings and conferences product for the small meetings segment. However, the potential of some specific locations in the Norte region should not be forgotten, as they have excellent hotel facilities perfect for corporate retreats, which could please company administrators since these places do not have many nearby distractors.
In 2006, nature tourism represented $6 \%$ of the primary motivations for tourists visiting Portugal. Despite the fact that $21 \%$ of the country is classified as protected areas, nature tourism in the Norte region presents clear gaps in terms of infrastructure, services, locals' experience and know-how and non-competitive companies operating in this field. The main challenge is to develop a tourism offer that respects the environment. The goal is to make it possible to sell this product to tourists while preserving protected areas.

Health and wellness tourism has steadily increased in Portugal. This product is divided into three segments: thermal springs, spas and specialised clinics. In terms of infrastructure, the Norte region has many thermal springs, but a great majority are associated with antiquated installations and a limited range of services and activities available to tourists. If properly planned and structured, the segment of thermal springs could seek to create an offer with a high degree of differentiation based on the quality of their mineral water. For this to happen in the Norte region, it is necessary to change from a business model based on health treatments to that of wellness and to promote properly good existing facilities, for instance, the Vidago Palace Hotel, closed in 2006 for renovation and reopened in 2010 for its centenary.

In 2004, the European wine-gastronomy and cultural tourism market increased to 600,000 trips per year. By 2014, this market had grown to 1.2 million trips per year, in other words, a 7\% annual growth rate. In general, higher spending levels are related to learning and knowledge-related group trips, as these include thematic activities, for example, courses or workshops. The Norte region needs to use its outstanding 'epicurean' heritage in order to create a stronger gastronomical identity, which is why this region needs to be given priority in investment in wine-gastronomy products. Through the development of this diverse set of priority tourism products, Portugal's Norte region can be expected to increase its capacity to generate tourist attractions in response to the aforementioned challenges and defined objectives.

Table 3 shows the priority sub regions for investments in primary tourism products (Business; Urban; Nature; Nautical; Gastronomy and wines; Health and wellness; Cultural and historic and Golf) that the northern region should strongly develop. 
Table 3 - Tourism products for tourist subregions in the north of Portugal

\begin{tabular}{|c|c|c|c|c|}
\hline $\begin{array}{c}\text { Subregions strategic } \\
\text { tourism products }\end{array}$ & $\begin{array}{c}\text { Oporto } \\
\text { Metropolitan area }\end{array}$ & Alto Minho & Douro & $\begin{array}{c}\text { Terras de } \\
\text { Trás-os- Montes }\end{array}$ \\
\hline Business tourism & $\mathrm{M}$ & & & \\
\hline Urban tourism & $\mathrm{M}$ & & & \\
\hline Nature tourism & & $\mathrm{M}$ & $\mathrm{M}$ & $\mathrm{M}$ \\
\hline Nautical tourism & $\mathrm{M}$ & $\mathrm{H}$ & $\mathrm{M}$ & $\mathrm{H}$ \\
\hline Gastronomy and wine tourism & $\mathrm{H}$ & $\mathrm{M}$ & $\mathrm{M}$ & $\mathrm{H}$ \\
\hline Health and wellness tourism & $\mathrm{H}$ & $\mathrm{H}$ & $\mathrm{H}$ & $\mathrm{M}$ \\
\hline Cultural and historic tourism & $\mathrm{M}$ & $\mathrm{M}$ & $\mathrm{M}$ & $\mathrm{M}$ \\
\hline Golf & $\mathrm{H}$ & $\mathrm{H}$ & $\mathrm{H}$ & $\mathrm{H}$ \\
\hline
\end{tabular}

Priority level: Maximum (M); High (H).

Source: Authors; adapted from CCDR-N (2008a, p. 94).

In 2007, based on the data collected in previous years and the growth forecast expected for the tourism sector, PENT set realistic goals but ambitious to achieve in the period 2006 to 2015. According to available tourism resources and products to develop, the Norte Region should be the national destination with one of the highest performances in growth terms. Table 4 summarizes the targets to be achieved for Portugal and the Northern Region in the tourism sector.

Table 4 - Goals to achieve according to PENT

\begin{tabular}{|l|l|l|}
\hline Outcomes to be achieved 2006-2015 & \multicolumn{1}{|c|}{ Portugal } & \multicolumn{1}{|c|}{ Norte Region } \\
\hline Number of Overnight Stays & $\begin{array}{l}\text { Reach } 38 \text { million international tourists' } \\
\text { overnights, is forecast to grow at an average } \\
\text { annual rate of 4.5\%. }\end{array}$ & $\begin{array}{l}\text { Foreseeing annual growth rate of } 8.5 \% . \\
\text { Attaining over } 1,7 \text { million international tourists' } \\
\text { overnights in } 2015 . \\
\text { Annual growth of 2.9\% in the number of national tourists. }\end{array}$ \\
\hline Number of tourists & $\begin{array}{l}2015-\text { Reach between } 20 \text { to } 21 \text { million } \\
\text { international tourists' overnights; annual } \\
\text { growth of } 5 \% \text { in the number of international } \\
\text { tourists and 2,9\% in the number of national } \\
\text { tourists. }\end{array}$ & $\begin{array}{l}2015 \text { Annual growth of } 7,5 \% \text { in the number of } \\
\text { international tourists. }\end{array}$ \\
\hline $\begin{array}{l}\text { Tourism revenue } \\
\text { (total income) }\end{array}$ & $\begin{array}{l}15.5 \text { billion euros. Revenues should grow at } \\
\text { an annual rate of } 9 \% .\end{array}$ & Revenues should grow at an annual rate of 11\%. \\
\hline
\end{tabular}

Source: Authors; adapted from Turismo de Portugal (2007).

\section{Methods and Results}

In this research we are going to organize and analyse data supplied by the INE, PENT, CCDR-N, Tourism of Portugal and Tourism of Oporto and Northern Portugal between 2004 and 2014, and compare the results obtained with the PENT targets. Tourism is a transversal activity, with strong dependence of its territorial resources for its own economic, social and environmental sustainability. Thus, the definition of policies and strategies for the development of tourism in a region must take into account several aspects. The strong ambition to make tourism as one of the main engines of growth and economic development is only possible with a demanding and appropriate set of specific objectives. The ART based on the defined objectives of PENT established the following strategic goals for tourism (CCDR-N, 2008a): Qualify and evaluate tourism resources to strengthen the priority of tourism products and improve infrastructure support; Increase the supply of accommodation, and enhance animation, with due consideration of quality and durability; Promote the qualifications of tourism industry employees through better human resources training; Promote tourism in northern Portugal and its 4 sub regions, as well as their primary tourism products and Provide assistance and information on regional tourism.
Portugal is a small country on the southwestern 'Atlantic Arch' periphery of Europe, which has experienced accelerated socioeconomic change since the return to democracy in 1974 and full membership in the EU in 1986 (Eduards \& Fernandes, 1999). The Norte region is where Portugal was founded in the twelfth century and became a country. The Norte region boasts the Atlantic coastline with the most international goods traffic to and from the EU of the Iberian Peninsula, out of the Port of Leixões. This distinction also extends to the existence in this region of one of the best airports in Europe - the Francisco Sá Carneiro Airport, regarded as the most important airport in the North of the Iberian Peninsula, in terms of traffic volume, area of influence and connectivity. With a capacity for six million passengers per year, it offers about 70 destinations. Oporto, a UNESCO World Heritage city (i.e. in 1996) is known not only for its Port wine all over the world but also for a heritage that combines ancient churches and monuments, such as the Cathedral and the Church of São Francisco, and modern buildings, such as the House of Music and the Serralves Museum. In this region of mountains and natural parks, the area's heritage can be seen not only in its castles, such as in Guimarães, but also in the Baroque architecture of stone and gilded carvings set side by side with simpler rural chapels. Its cities, which retain a human scale, include Viana do Castelo, Braga, Lamego, Chaves and Vila Real. 
The population of northern Portugal in 2004 was about 3.72 million, which decreased to around 3.62 million in 2014, at which time this represented $35 \%$ of the total population of Portugal (see Table 3). For example, the Alto Tâmega had, in 2004, a resident population of 557,762 inhabitants, which subsequently declined considerably to 90,211 in 2014, when it was $2.4 \%$ of the Norte region and $0.9 \%$ of Portugal's population. The population density in the Norte region in 2004 was approximately 175 people per square kilometre, varying between the extremes of
40 and 623 inhabitants in Terras de Trás-os-Montes and Oporto, respectively. In 2014, the population density in the Norte region was approximately 170 people per square kilometre, varying between the extremes of 20 and 848 inhabitants, again, in Terras de Trás-os Montes and Oporto, respectively (adapted from INE [2005] and INE [2015a]). This population exodus has characterised the demographics of the Norte region for many decades, being particularly pronounced in the 60s, 70s and $80 \mathrm{~s}$ and continuing between 2004 and 2014 (see Table 5).

Table 5 - Some characteristics of the Norte region

\begin{tabular}{|c|l|c|c|c|}
\hline & & Resident population (2004) & Resident population (2014) & Area $^{\left(\mathbf{k m}^{\mathbf{2}}\right)}$ \\
\hline NUTS I & Portugal & $10,529,255$ & $10,374,822$ & $92,225.64$ \\
\hline NUTS II & Norte & $3,727,310$ & $3,621,785$ & $21,285.88$ \\
\hline \multirow{3}{*}{$\begin{array}{l}\text { NUTS } \\
\text { III }\end{array}$} & Alto Minho & 251,937 & 237,997 & $2,218.84$ \\
\cline { 2 - 5 } & Cávado & 404,681 & 407,420 & $1,245.79$ \\
\cline { 2 - 5 } & Ave & 519,542 & 419,826 & $1,451.32$ \\
\cline { 2 - 5 } & Área Metropolitana do Porto & $1,272,176$ & $1,731,354$ & $2,041.31$ \\
\cline { 2 - 5 } & Alto Tâmega & 557,762 & 90,211 & $2,921.91$ \\
\cline { 2 - 5 } & Tâmega e Sousa & 283,856 & 425,588 & $1,831.52$ \\
\cline { 2 - 5 } & Douro & 217,067 & 197,210 & $4,031.58$ \\
\cline { 2 - 5 } & Terras de Trás-os-Montes & 220,289 & 112,179 & $5,543.61$ \\
\hline
\end{tabular}

Source: Authors; adapted from data from INE (2005) and INE (2015a).

In 2014, the accommodation sector was composed of 3,578 active companies, 1,624 more establishments than in 2004 (see Table 6). These were distributed as hotel establishments $(1,550)$, local accommodations $(1,145)$ and rural tourism and housing tourism (883), resulting in a positive increase of $54.6 \%$.

Table 6 - Tourism accommodation establishments in the Norte region, 2004-2014

\begin{tabular}{|c|c|c|c|c|c|c|c|c|c|c|c|}
\hline Year of reference & 2004 & 2005 & 2006 & 2007 & 2008 & 2009 & 2010 & 2011 & 2012 & 2013 & 2014 \\
\hline Portugal & 1,954 & 2,012 & 2,028 & 2,031 & 2,041 & 1,988 & 2,011 & 2,019 & 2,028 & 3,345 & 3,578 \\
\hline Norte & 435 & 450 & 452 & 461 & 465 & 450 & 441 & 453 & 463 & 860 & 922 \\
\hline
\end{tabular}

Source: Authors, adapted from data from INE (2016).

The lodging capacity of these hotel establishments was 253,927 beds in 2004 . This number, still rising, was registered as 342,497 beds in 2014 (see Figure 3).

Figure 3 - Lodging capacity of hotel establishments by NUTS III regions

\section{4}

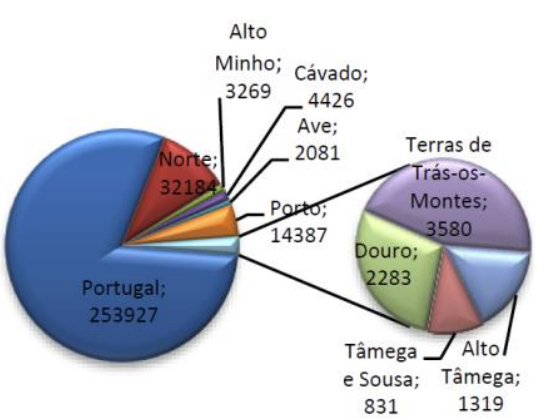

In 2014, there were 6 million overnight stays spent in hotel establishments, local accommodation, rural tourism and housing tourism in the Norte region, which corresponds to $12.4 \%$ of the

\section{4}

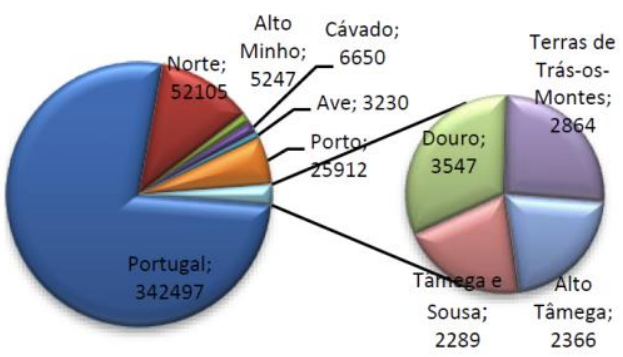

total of 49 million overnight stays registered at the national level (see Table 7).

Table 7 - Tourism activity indicators - Nights spent in tourism accommodations in the Norte region, 2004-2014 (in millions)

\begin{tabular}{|c|c|c|c|c|c|c|c|c|c|c|c|}
\hline Year of reference & 2004 & 2005 & 2006 & 2007 & 2008 & 2009 & 2010 & 2011 & 2012 & 2013 & 2014 \\
\hline Portugal & 34,1 & 35,5 & 37,5 & 39,7 & 39,2 & 36,4 & 37,3 & 39,4 & 39,6 & 43,5 & 48,7 \\
\hline Norte & 3,3 & 3,4 & 3,8 & 4,2 & 4,2 & 4,2 & 4,4 & 4,5 & 4,5 & 5,2 & 6,0 \\
\hline
\end{tabular}

Source: Authors; adapted from data from INE (2016). 
According to PENT, Portugal aims to achieve the following levels of annual growth: $5 \%$ in terms of the number of tourists, rising to 20 million tourists in 2015. In 2014, there were 17 million and
3 million tourists, in entire country and in Norte region, respectively (see Table 8).

Table 8 - Tourism activity indicators - Number of tourists, in the Norte region, 2004-2014 (in millions)

\begin{tabular}{|c|c|c|c|c|c|c|c|c|c|c|c|}
\hline Year of reference & $\mathbf{2 0 0 4}$ & $\mathbf{2 0 0 5}$ & $\mathbf{2 0 0 6}$ & $\mathbf{2 0 0 7}$ & $\mathbf{2 0 0 8}$ & $\mathbf{2 0 0 9}$ & $\mathbf{2 0 1 0}$ & $\mathbf{2 0 1 1}$ & $\mathbf{2 0 1 2}$ & $\mathbf{2 0 1 3}$ & $\mathbf{2 0 1 4}$ \\
\hline Portugal & 10,9 & 11,4 & 12,3 & 13,3 & 13,4 & 12,9 & 13,5 & 13,9 & 13,8 & 15,2 & 17,3 \\
\hline Norte & 1,8 & 1,9 & 2,1 & 2,3 & 2,4 & 2,4 & 2,5 & 2,6 & 2,6 & 2,9 & 3,3 \\
\hline
\end{tabular}

Source: Authors; adapted from data from INE (2016).

In 2005, the hotel accommodation sector pulled in EUR€ 1060 million, approximately the same as the previous year. Compared to the results for 2004 , the Norte showed a decline of $-6.2 \%$ in room revenues. In 2014, revenue from accommodations totalled EUR€ 1.6 million (+18.8\%) at the national level (see Table 9).

Table 9 - Lodging income in tourism accommodation establishments, 2004-2014 (in millions of Euros)

\begin{tabular}{|l|c|c|c|c|c|c|c|c|c|c|c|}
\hline Year of reference & $\mathbf{2 0 0 4}$ & $\mathbf{2 0 0 5}$ & $\mathbf{2 0 0 6}$ & $\mathbf{2 0 0 7}$ & $\mathbf{2 0 0 8}$ & $\mathbf{2 0 0 9}$ & $\mathbf{2 0 1 0}$ & $\mathbf{2 0 1 1}$ & $\mathbf{2 0 1 2}$ & $\mathbf{2 0 1 3}$ & $\mathbf{2 0 1 4}$ \\
\hline Portugal & 1060 & 1059 & 1153 & 1301 & 1323 & 1190 & 1225 & 1307 & 1290 & 1370 & 1627 \\
\hline Norte & 115 & 107 & 121 & 137 & 143 & 140 & 150 & 153 & 149 & 158 & 194 \\
\hline
\end{tabular}

Source: Authors; adapted from data from INE (2016).

\section{Discussion of Results}

By the data collect from several sources, we notice that during 2004 to 2014 period, the tourism sector continued to consolidate its importance for the Portuguese economy, growing in general in all the indicators for the activity.

In Norte Region, from 2004 to 2014 the number of tourism accommodation establishments increased by $112 \%$, while in Portugal increased only $83,1 \%$. The Norte region of Portugal had 435 of Portugal's 1954 tourism accommodation establishments in 2004 and 922 of the country's 3578 tourism accommodation establishments in 2014, which represents a share of $22.3 \%$ and $25.8 \%$, respectively. Tourism's performance showed also interesting growth rates when compared with the previous year $-7,2 \%$ and $6,97 \%$ more establishments, in Norte and in Portugal, respectively.

Furthermore, tourism's performance showed also interesting growth rates when compared with the previous year $-9,8 \%$ and $12,4 \%$ more overnight stays, in Norte and in Portugal, respectively. The evolution of the number of overnight stays from 2004 to 2014 in northern Portugal has some significant differences when compared to the entire country. Thus, while Portugal, during those years, saw an increase of $42.7 \%$ in the number of nights spent, northern Portugal experienced, in the same period, an increase of $82 \%$. In other words, there is a difference of about $39 \%$, almost double that of the entire country. Moreover, quite significantly, the most overnight stays recorded in the north of Portugal during the 11 years under review appeared specifically in 2014. During the period in question, there were some inconsistences in the evolution of overnight stays (i.e. decreasing and increasing).

The number of beds (i.e. lodging capacity) almost doubled between 2004 (32184 beds) and 2014 (52105) in the Norte region.

Tourism's performance showed more interesting growth rates when compared with the previous year (2013) - 13,8\% more guests in Portugal, when compared with 9,9\% in 2012 or with $1,1 \%$ in 2011 . The level of annual growth in terms of the number of tourist was bigger than 5\%, in 2014, 2013, 2007, 2006 and 2005 with respect to Portugal and in 2014, 2013, 2007 and 2006 with respect to Norte Region.

Net revenues obtained by the Norte's hospitality sector increased every year between 2005 and 2014 from 107873 to 194508 thousands of EUR€. Compared to the results for 2013, the Norte showed an increase of $22.7 \%$ in room revenues, more than the national level of $18.8 \%$. It should be noted that the growth rate in revenue from tourism, in 2014 , was $18,8 \%$ and $22,7 \%$, in Portugal and Norte, respectively, contributed positively towards balancing the balance of trade. Although in 2014, the tourism revenues were higher than the goal set by PENT, in the previous years were below the goal.

\section{Conclusion}

Tourism has great strategic importance for the Portuguese economy due to its capacity for wealth-generation and jobcreation, contributing to the country's competitiveness, richness and cohesion. It is one of the few sectors where Portugal has strong competitive benefits. Thus, the government and tourism stakeholders have recently made a stronger commitment to developing this sector. Given the growing importance of tourism in the national economy, throughout this study, we analyzed two key strategic plans for the development of tourism in the Northern Region: National Strategic Plan for Tourism (PENT) and Regional North Tourism Agenda (ART). To understand the achievement of these plans, we made a descriptive analysis of the main indicators of tourism between 2004 and 2014, for the Northern Region of Portugal and concluded that the tourist focus of the Northern Region has the offer of eight (Business tourism; Urban tourism; Nature tourism; Nautical tourism; Gastronomy and wines tourism; Health and wellness tourism; Cultural and historic and Golf tourism) priority tourism products and differentiators for four tourist sub regions (Oporto Metropolitan Area, Alto Minho, Douro and Terras de Trás-os-Montes). 
Comparing the forecast values in terms of overnight stays, tourists and revenue with the targets set by PENT, the reality given by the data collected from some sources, namely the INE, showed that the results were far from the expected, although in the last two years have exceeded the expectations, perhaps largely due to the period of instability in financial markets and to moderate economic growth of the European economy, main source of tourists for Portugal.

After this study of the tourism sector in northern Portugal, the next step would be to ascertain if the investments made are having the desired economic, social and environmental impacts on the region. This research is a massive challenge that we will seek to meet in the near future.

\section{References}

Benur, A. \& Bramwell, B. (2015). Tourism product development and product diversification in destinations, Tourism Management, 50, 213-224, doi:10.1016/j.tourman.2015.02.005.

CCDR-N (2006). Norte 2015, Competitividade e Desenvolvimento - Uma Visão Estratégica, Comissão de Coordenação e Desenvolvimento Regional do Norte. Porto.

CCDR-N (2008a). Plano de Ação para o Desenvolvimento Turístico do Norte de Portugal, Comissão de Coordenação e Desenvolvimento Regional do Norte. Porto. Retrieved 25 July 2017 from http://www.ccdr-n.pt/sites/default/files/planoaccaoturismo.pdf.

CCDR-N (2008b). Plano Desenvolvimento Turístico do Vale do Douro 2007-2013, Comissão de Coordenação e Desenvolvimento Regional do Norte. Porto. Retrieved 25 July 2017 from http://www.ccdrn.pt/sites/default/files/ficheiros_ccdrn/missaodouro/pdtvd_2007_ 2013.pdf.

Choi, H. C., \& Sirakaya, E. (2005). Measuring residents' attitudes toward sustainable tourism: development of sustainable tourism attitude scale. Journal of Travel Research, 43(4), 380-394.

Crotti, R. \& Misrahi, T. (2015). The Travel \& Tourism Competitiveness Report 2015 - Growth through Shocks. World Economic Forum. Retrieved $25 \quad$ July 2017 from http://www3.weforum.org/docs/TT15/WEF_Global_Travel\&Touris m_Report_2015.pdf

Eduards, J. \& Fernandes, C. (1999). Emigrants and Espigueiros - Tourism Activities in a Peripheral Area of Portugal. International Journal of Tourism Research, 1, 329-340.

Fernandes, P. \& Cepeda, F. (2002). Produtos Turísticos para o Nordeste Transmontano. XII Jornadas Luso Espanholas de Gestão Científica/Novos Desafios na Gestão: Inovação ou Renovação. Publicação em Actas. Volume IV-Marketing. Covilhã: Universidade da Beira Interior.

INE (2005), Anuário Estatístico da Região Norte 2004 / Statistical Yearbook of Norte Region 2004. Lisbon: Instituto Nacional de Estatística.

INE (2015a), Anuário Estatístico da Região Norte 2014 / Statistical Yearbook of Norte Region 2014. Lisbon: Instituto Nacional de Estatística.

INE (2015b), Anuário Estatístico de Portugal 2014 / Statistical Yearbook of Portugal 2014. Lisbon: Instituto Nacional de Estatística.

INE (2016), Instituto Nacional de Estatística. Dados Estatísticos. Retrieved 28 September 2016 from https://www.ine.pt/xportal/xmain?xpid=INE\&xpgid=ine_base_dados

Kim, W. \& Kim, H. (2013). Regional Development Strategy for Increasing Cultural Tourism Business in South Korea. Asia Pacific Journal of
Tourism Research, 18(6), 10.1080/10941665.2012.695285.

Lage, B. \& Milone, P. (2001). Economia do Turismo (7ạ Edição). São Paulo: Atlas S.A.

Leitão, N. (2011). Tourism and Economic Growth: A Panel Data Approach, Instituto Politécnico de Santarém. Actual Problems of Economics, 9, 343-349.

Makhlouf, H. (2012). The Multi-Dimensional Impact of International Tourism. International Business \& Economics Research Journal, 11(2), 233-241.

Masiero, L. \& Nicolau, J. (2012). Price sensitivity to tourism activities: looking for determinant factors, Tourism Economics Journal, 18(4), 675-689, doi: 10.5367/te.2012.0143.

Middleton, V., Fyall, A., Morgan, M. \& Ranchhod, A. (2009). Marketing in Travel and Tourism. (4th ed.), Oxford: Butterworth-Heinemann.

Ministério da Economia e do Emprego (2012). Plano Estratégico Nacional do Turismo: Revisão do Plano de Desenvolvimento do Turismo no horizonte 2015. Retrieved 28 August 2016 from http://www.turismodeportugal.pt/Portugu\%C3\%AAs/turismodepo rtugal/publicacoes/Documents/PENT\%202012.pdf.

Patel, I. S. \& Nayab, Z.A. (2014). Introduction to tourism, Geography of Transport, Tourism and Management. Solapur: Solapur University.

Santos, N. (2011). Modelação da Procura Turística para a Região Norte de Portugal - Masters Dissertation, Instituto Politécnico de Bragança. Bragança.

Silva, J., Rodrigues, P., Mendes, J., \& Pereira, L. (2010). A Tourism Research Agenda for Portugal. International Journal of Tourism Research, 12, 90-101. Doi: 10.1002/jtr.740.

Smith, S. (1994). The Tourism product. Annals of Tourism Research, 21(3), 582-595.

Turismo de Portugal (2007). Plano Estratégico Nacional do Turismo (PENT) - para o desenvolvimento do turismo em Portugal. Turismo de Portugal, I.P. Lisboa. Retrieved 28 July 2016 from http://www.turismodeportugal.pt/Portugu\%C3\%AAs/turismodepo rtugal/publicacoes/Documents/PENT\%202007.pdf.

Turismo de Portugal, IP (2014), Turismo 2020 - Plano de Ação para o Desenvolvimento do Turismo em Portugal 2014 - 2020. Retrieved 28 September 2016 from http://turismo2020.turismodeportugal.pt/fotos/editor2/turismo20 20_parte i mercados-swot.pdf.

UNWTO (2015). World Tourism Organization (UNWTO) - Annual Report 2014 (2015). Retrieved 15 September 2016 from http://cf.cdn.unwto.org/sites/all/files/pdf/unwto_annual_report_2 014.pdf.

Visser, G. (2003). South Africa tourism and its role in the perpetuation of an uneven tourism space economy. Africa Insight, 33(1/2), 116-123.

Weiermair, K. (2004). Product Improvement or Innovation: What is the Key to Success in Tourism? Paris: OECD.

WTTC (2016). 2016 Economic Impact Annual Update Summary. $\begin{array}{llll}\text { Retrieved } & 24 & \text { September } & 2016\end{array}$ http://www.wttc.org/research/economic-research/economicimpact-analysis

$\mathrm{Xu}$, J. (2010). Perceptions of tourism products, Tourism Management, 31(5), 607-610, doi: 10.1016/j.tourman.2009.06.011

Received: 03 January 2017

Revisions required: 06 February 2017

Accepted: 20 April 2017 